\title{
The uncoupling protein I gene, UCPI, is expressed in mammalian islet cells and associated with acute insulin response to glucose in African American families from the IRAS Family Study
}

\author{
Michèle M Sale*1,2,3, Fang-Chi Hsu ${ }^{4}$, Nicholette D Palmer ${ }^{1,5}$, \\ Candace J Gordon ${ }^{1}$, Keith L Keene ${ }^{1}$, Hermina M Borgerink ${ }^{6}$, Arun J Sharma ${ }^{7}$, \\ Richard N Bergman ${ }^{8}$, Kent D Taylor ${ }^{9}$, Mohammed F Saad ${ }^{10}$ and \\ Jill M Norris ${ }^{11}$
}

Address: ${ }^{1}$ Center for Human Genomics, Wake Forest University School of Medicine, Winston-Salem, USA, ${ }^{2}$ Department of Internal Medicine, Wake Forest University School of Medicine, Winston-Salem, USA, ${ }^{3}$ Center for Public Health Genomics and Department of Medicine, University of Virginia, Charlottesville, USA, ${ }^{4}$ Department of Biostatistical Sciences, Wake Forest University School of Medicine, Winston-Salem, USA,

${ }^{5}$ Department of Biochemistry, Wake Forest University School of Medicine, Winston-Salem, USA, ${ }^{6}$ Department of Comparative Medicine, Wake Forest University School of Medicine, Winston-Salem, USA, ${ }^{7}$ Joslin Diabetes Center and Harvard Medical School, Boston, USA, ${ }^{8}$ Department of Physiology and Biophysics, Keck School of Medicine, University of Southern California School of Medicine, Los Angeles, USA, ${ }^{9}$ Medical Genetics Institute, and Division of Cardiology, Department of Medicine, Cedars-Sinai Medical Center, Los Angeles, USA, ${ }^{10}$ Department of Preventive Medicine, Stony Brook School of Medicine, Stony Brook, USA and ${ }^{11}$ Department of Preventive Medicine and Biometrics, University of Colorado Health Sciences Center, Denver, USA

Email: Michèle M Sale* - msale@virginia.edu; Fang-Chi Hsu - fhsu@wfubmc.edu; Nicholette D Palmer - npalmer@wfubmc.edu; Candace J Gordon - cfranck@mwgdna.com; Keith L Keene - kkeene@wfubmc.edu; Hermina M Borgerink - hborgeri@wfubmc.edu; Arun J Sharma - Arun.Sharma@joslin.harvard.edu; Richard N Bergman - rbergman@usc.edu; Kent D Taylor - Kent.Taylor@cshs.org; Mohammed F Saad - mosaad@notes.cc.sunysb.edu; Jill M Norris - Jill.Norris@uchsc.edu

* Corresponding author

Published: 30 March 2007

BMC Endocrine Disorders 2007, 7:1 doi:10.1186/1472-6823-7-1
Received: I August 2006

Accepted: 30 March 2007

This article is available from: http://www.biomedcentral.com/1472-6823/7/I

(C) 2007 Sale et al; licensee BioMed Central Ltd.

This is an Open Access article distributed under the terms of the Creative Commons Attribution License (http://creativecommons.org/licenses/by/2.0), which permits unrestricted use, distribution, and reproduction in any medium, provided the original work is properly cited.

\begin{abstract}
Background: Variants of uncoupling protein genes UCPI and UCP2 have been associated with a range of traits. We wished to evaluate contributions of known UCPI and UCP2 variants to metabolic traits in the Insulin Resistance and Atherosclerosis (IRAS) Family Study.

Methods: We genotyped five promoter or coding single nucleotide polymorphisms (SNPs) in 239 African American (AA) participants and 583 Hispanic participants from San Antonio (SA) and San Luis Valley. Generalized estimating equations using a sandwich estimator of the variance and exchangeable correlation to account for familial correlation were computed for the test of genotypic association, and dominant, additive and recessive models. Tests were adjusted for age, gender and BMI (glucose homeostasis and lipid traits), or age and gender (obesity traits), and empirical P-values estimated using a gene dropping approach.

Results: UCPI A-3826G was associated with $A_{I R}$ in $A A(P=0.006)$ and approached significance in Hispanic families $(P=0.054)$; and with HDL-C levels in SA families $(P=0.0004)$. Although UCPI expression is reported to be restricted to adipose tissue, $R T$ $P C R$ indicated that UCPI is expressed in human pancreas and MIN-6 cells, and immunohistochemistry demonstrated colocalization of UCPI protein with insulin in human islets. UCP2 A55V was associated with waist circumference $(P=0.045)$ in $A A$, and $B M I$ in SA $(P=0.018)$; and $U C P 2$ G-866A with waist-to-hip ratio in AA $(P=0.016)$.

Conclusion: This study suggests a functional variant of UCPI contributes to the variance of AIR $\mathrm{g}$ in an $A A$ population; the plausibility of this unexpected association is supported by the novel finding that UCPI is expressed in islets.
\end{abstract}




\section{Background}

Uncoupling proteins are mitochondrial inner membrane electron carriers [1]. Uncoupling protein 2 (UCP2) inhibits glucose stimulated insulin secretion, and models of type 2 diabetes are associated with increased expression in islets [2]. Polymorphisms in the uncoupling protein genes UCP1 (4q31.21) and UCP2 (11q13.4) have been associated with a number of measures of glucose homeostasis and adiposity. These include associations between UCP2 G866A and A55V and glucose-induced insulin secretion [3-5], as well as obesity and metabolism [6-8]. Associations with obesity, weight gain and metabolism [9-12] have been reported for UCP1 variant A3826G, often acting synergistically with $\beta 3$-adrenergic receptor W64R, and UCP1 A64T has also been associated with obesity [10]. In addition, UCP1 A-3826G and M229L have been found to be associated with type 2 diabetes [11,13].

Given the importance of $U C P 1$ and $U C P 2$ genes in metabolism, we chose to evaluate the five promoter or coding variants in these two genes previously associated with metabolic phenotypes (above) for associations in families from the Insulin Resistance and Atherosclerosis (IRAS) Family Study. The IRAS Family Study has recruited extended African American and Hispanic families [14], and extensive phenotypic data on measures of glucose homeostasis, adiposity, and lipids have been collected on participants. On detection of a significant association between UCP1 SNPs and acute insulin response to glucose $\left(\mathrm{AIR}_{\mathrm{g}}\right)$, we investigated the expression patterns of this gene in mammalian pancreas.

\section{Methods \\ Subjects}

The IRAS Family Study design, recruitment and phenotyping have been described in detail [14]. Studies were con- ducted using protocols approved by the human subjects committees at each participating institution and all participants provided informed consent. Briefly, multi-generational African American and Hispanic families were initially recruited from probands of the original IRAS cohort [15]. Ascertainment of the proband was based on the sample size of available family members (with a target of four living full siblings and five living offspring of these siblings) and a range of glucose tolerance. Ascertainment was supplemented with additional large non-IRAS families recruited from the general population. Families were not selected based on any phenotypic criteria. Participants were from clinical centers in Los Angeles, California (African American), San Luis Valley, Colorado (rural Hispanic), and San Antonio, Texas (urban Hispanic). The clinical examination included height, weight, waist and hip circumferences, fasting blood draw, computerized tomography (CT) scanning for assessment of abdominal fat area, and medical history interview. A total of 287 African American individuals ( 18 families; family size ranged from 4 to 51 family members) from Los Angeles, 318 Hispanic individuals (12 families; family size 4 to 39 members) from San Luis Valley and 493 Hispanic individuals (33 families; family size from 6 to 30 members) from San Antonio were included in the analyses (Table 1).

\section{Glucose homeostasis traits}

The following traits related to glucose homeostasis were tested for association with the UCP1 and UCP2 SNPs genotyped: fasting plasma glucose; fasting plasma insulin; acute insulin response to glucose $\left(\mathrm{AIR}_{\mathrm{g}}\right)$; and insulin resistance, expressed as the insulin sensitivity index $\left(\mathrm{S}_{\mathrm{I}}\right)$. Glucose values were obtained after a minimum 8 hour fast. Plasma glucose and insulin levels were measured at the University of Southern California, using the glucose oxidase technique on an autoanalyzer and the insulin

Table I: IRAS Family Study participant characteristics

\begin{tabular}{|c|c|c|c|}
\hline & \multirow{2}{*}{$\begin{array}{c}\text { African American } \\
\text { Los Angeles }\end{array}$} & \multicolumn{2}{|c|}{ Hispanic } \\
\hline & & San Luis Valley & San Antonio \\
\hline Families (n) & 18 & 12 & 33 \\
\hline Family members per family (n) & $4-51$ & $4-39$ & $6-30$ \\
\hline Participantsa (n) & 287 & 318 & 493 \\
\hline Female gender, $\%$ & 56.5 & 52.2 & 60.0 \\
\hline Diabetes, \% & 11.6 & 12.8 & 17.7 \\
\hline Age, mean \pm SD & $43.8 \pm 14.8$ & $40.3 \pm 14.0$ & $43.6 \pm 14.8$ \\
\hline $\mathrm{AIR}_{\mathrm{g}} \mu \mathrm{U} / \mathrm{mL} \pm \mathrm{SD}$ & $878.4 \pm 768.2$ & $808.1 \pm 631.5$ & $726.2 \pm 620.1$ \\
\hline $\mathrm{S}_{\mathrm{l}}, \mathrm{MINMOD}, \pm \mathrm{SD}$ & $1.75 \pm 1.22$ & $2.41 \pm 2.00$ & $1.95 \pm 1.85$ \\
\hline $\mathrm{BMI}, \mathrm{kg} / \mathrm{m}^{2} \pm \mathrm{SD}$ & $28.8 \pm 6.5$ & $27.5 \pm 5.6$ & $30.1 \pm 6.3$ \\
\hline Waist, $\mathrm{cm} \pm \mathrm{SD}$ & $89.3 \pm 14.1$ & $87.3 \pm 13.2$ & $92.9 \pm 14.7$ \\
\hline WHR, ratio \pm SD & $0.82 \pm 0.08$ & $0.85 \pm 0.09$ & $0.85 \pm 0.08$ \\
\hline $\mathrm{HDL}, \mathrm{mg} / \mathrm{dL} \pm \mathrm{SD}$ & $48.3 \pm 13.2$ & $43.7 \pm 12.4$ & $42.4 \pm 12.9$ \\
\hline
\end{tabular}

aIncludes only individuals from the IRAS Family Study cohort with at least one UCPI or UCP2 SNP genotype. Individuals in these families with type 2 diabetes have been excluded from $A I R_{g}$ and $S_{1}$ calculations. AIR ${ }_{g}$ : Acute insulin response to glucose; $S_{l}$ : insulin sensitivity index; WHR: waist-to-hip ratio. 
dextran-charcoal immunoassay [16]. Insulin sensitivity was assessed by the frequently sampled intravenous glucose tolerance test (FSIGT), using a reduced sampling protocol [17]. Glucose in the form of a $50 \%$ solution $(0.3 \mathrm{~g} /$ $\mathrm{kg})$ and regular human insulin $(0.03 \mu / \mathrm{kg})$ were injected through an intravenous line at 0 and $20 \mathrm{~min}$, respectively. Blood was collected at $-5,2,4,8,19,22,30,40,50,70$, 100 , and $180 \mathrm{~min}$. Insulin resistance, expressed as the insulin sensitivity index $\left(\mathrm{S}_{\mathrm{I}}\right)$, was calculated by mathematical modeling methods (MINMOD) [18]. Acute insulin response to glucose $\left(\mathrm{AIR}_{\mathrm{g}}\right.$ ) was defined as the mean insulin increment in the plasma insulin concentration above the basal in the first 8 min after the administration of glucose. Glucose values were obtained after a minimum 8 hour fast, and diabetes was diagnosed using the American Diabetes Association criteria of fasting plasma glucose value $\geq 126 \mathrm{mg} / \mathrm{dL}$ and/or current use of anti-diabetic medications. Individuals with diabetes were excluded for analyses of glucose homeostasis traits. One hundred eighty-five participants had impaired fasting glycemia (fasting glucose $>100 \mathrm{mg} / \mathrm{dL}$ ).

\section{Lipid traits}

Lipid traits tested for association with UCP1 and UCP2 SNPs included: triglyceride; HDL-C; LDL-C; and total cholesterol levels. Plasma was separated from blood collected after a $12 \mathrm{~h}$ fast, and stored at $-70^{\circ} \mathrm{C}$ prior to analysis. Total cholesterol and triglyceride were measured using enzymatic methods. LDL-C was calculated using the Friedewald equation [19] if triglyceride was $<400 \mathrm{mg} / \mathrm{dL}$ or otherwise by ultracentrifugation. HDL-C was measured using the direct method [20].

\section{Obesity and adiposity traits}

Obesity traits used for association analyses included: waist circumference; waist-to-hip ratio (WHR); BMI; visceral adipose tissue (VAT); and subcutaneous adipose tissue (SAT). Height, and waist and hip circumferences were measured to the nearest $0.5 \mathrm{~cm}$, and weight to the nearest $0.1 \mathrm{~kg}$. BMI was calculated as weight $(\mathrm{kg}) /$ height $(\mathrm{m})^{2}$. Abdominal fat mass was measured at the L2/L3 and L4/L5 vertebral region by CT. Scans were read at the University of Colorado Health Sciences Center, Department of Radiology, for VAT and SAT. Bowel fat was subtracted out from the VAT, and L4/L5 measures used in these analyses. A small number of participants were missing L4/L5 data but had L2/L3 data; for these participants L4/L5 data was imputed from the L2/L3 data using a simple linear model.

\section{UCPI and UCP2 genotyping}

Total genomic DNA was purified from whole blood using the PUREGENE DNA Purification kit (Gentra Systems, Minneapolis MN). Genotyping was conducted using a MassARRAY system (Sequenom, San Diego CA) [21]. Primer sequences for UCP1 A-3826G, A64T, M229L, and
UCP2 G-866A and A55V, designed using SpectroDESIGNER software (Sequenom, San Diego CA), are available on request.

\section{Statistical analyses}

Relationship testing and genotyping error checking

As part of the broader IRAS Family Study efforts, pedigrees were genotyped by the Mammalian Genotyping Service (MGS), Marshfield WI, using 383 microsatellite markers. Each pedigree was examined for consistency of the stated family structure with the genome scan data using PREST, version $2.01[22,23]$. In the 63 pedigrees used in this investigation, a total of 28 likely misspecified familial relationships were modified from 18 families. Genotypes that showed inconsistency with Mendelian inheritance were identified using PedCheck, version 1.1 [24], and inconsistent genotypes converted to missing. All SNPs were checked for consistency with Hardy Weinberg Equilibrium (HWE).

\section{Linkage disequilibrium}

We estimated the degree of linkage disequilibrium (LD) between SNPs using the standardized measure of D' [25], where the joint probability of haplotype was estimated by the expectation-maximization (EM) algorithm and the respective allele frequencies were estimated based on maximum likelihood estimates [26].

\section{Association analyses}

To explore associations among SNP polymorphisms and quantitative measures, the marginal models incorporating generalized estimating equations (GEE1) [27] were used. This approach has been widely used in longitudinal data analysis [28] and can account for the dependency between correlated measures within a family. The method allows separate modeling of the regression of quantitative measures on SNP polymorphisms and other covariates, and the association among quantitative measures within each family. An advantage of this method is that one need not to specify the distribution of the outcome variable, just the relationships between the marginal mean and variance, and between the marginal mean and covariates. Another advantage is that even though the correlation model among the related outcome measures may be specified incorrectly, the association model between the outcome and covariates can still obtain a robust result. Here familial correlation was accounted for using a sandwich estimator of the variance and exchangeable correlation. A family of power transformations conditional on the covariates age, gender, and BMI [29] was explored. To minimize the heterogeneity of variance, the phenotypes were transformed to best approximate the normality assumptions. We computed four tests of association for each SNP: the overall test of genotypic association with two degrees of freedom, as well as the statistical contrasts defined by 
three genetic models - dominant, additive, and recessive. Age, gender and BMI were included as covariates, except for measures of adiposity where analyses were conducted with and without BMI as a covariate. Marginal regression coefficients have the same interpretation as those from an analysis using unrelated individuals. Potential influential points and outliers have been checked. The analyses were stratified by center and performed using SAS software (SAS Institute, Cary, NC).

To avoid the potential increase of type I error rate, we estimated empirical pvalues for significant single SNP GEE association analyses $(\mathrm{P}<0.05$ using the general model, with mode of inheritance subsequently explored). We used the gene dropping approach implemented in Mendel, version 5.7 [30], to simulate 10,000 datasets based on the IRAS Family Study pedigree structure under the null hypothesis of no association between phenotype and genotype data. The empirical p-value was determined as the proportion of simulated data sets with statistics more extreme than the observed value. Only empirical p-values are presented since this approach is more conservative and adjusts for deficiencies in the large sample approximation of the GEE method.

Two-marker (UCP1 and UCP2) and three-marker (UCP1 only) haplotypic associations were evaluated in each population separately using quantitative pedigree disequilibrium tests (QPDT) [31].

\section{RT-PCR}

Reverse Transcription-PCR (RT-PCR) was performed using the SuperScript First Strand Synthesis System for RTPCR (Invitrogen Life Technologies, Carlsbad, CA), as described by the manufacturer, using $1 \mu \mathrm{g}$ total human pancreas RNA (Ambion, Austin, TX). Two $\mu$ l cDNA were subsequently amplified in a total reaction volume of $50 \mu \mathrm{l}$ containing $0.2 \mathrm{mM} \mathrm{dNTP}, 1.5 \mathrm{mM} \mathrm{MgCl}_{2}$, and $200 \mathrm{nM}$ of each forward and reverse primer. Primers were specifically designed in regions of low homology with the other UCP genes and flanking one or more introns. For human UCP1 the following primers were used: forward primer $5^{\prime}$ TGGAATAGCGGCGTGCTTG-3' (located in exon 1), and reverse primer 5'-CTCATCAGATTGGGAGTAG-3' (exon 4), expected to produce a product of $489 \mathrm{bp}$. For human UCP2, these primers were used: forward 5'-TCTACAATGGGCTGGTTGC-3' (exon 2) and reverse 5'TGTATCTCGTCTTGACCAC-3' (exon 5), with an expected product size of $495 \mathrm{bp}$. Control primers were for $\beta$-actin, supplied in the SuperScript First Strand Synthesis System for RT-PCR (Invitrogen Life Technologies, Carlsbad, CA). Each reaction was denatured at $95^{\circ} \mathrm{C}$ for 2 minutes, amplified using 40 cycles of $95^{\circ} \mathrm{C}$ for 30 seconds, $60^{\circ} \mathrm{C}$ for 45 seconds, and $72^{\circ} \mathrm{C}$ for 30 seconds, and underwent a final extension at $72{ }^{\circ} \mathrm{C}$ for 3 minutes. Samples were electrophoresed on a $1 \%$ agarose gel, products visualized under UV light, and compared against a Ready-Load $1 \mathrm{~Kb}$ Plus DNA Ladder (Invitrogen, Carlsbad, CA). Bands were extracted using a QIAquick Gel Extraction Kit microcentrifuge protocol (Qiagen Sciences, Valencia, CA) and sequenced on an ABI PRISM 3100 Genetic Analyzer (Applied Biosystems, Foster City, CA) using Big Dye Terminator v3.1 Cycle Sequencing Kits (Applied Biosystems, Foster City, CA).

Total RNA was extracted from MIN-6 or aTC 1.6 cells and reverse-transcribed to cDNA. 10 ng of cDNA was used in a $25 \mu \mathrm{l}$ PCR reaction with AmpliTaq Gold Polymerase, using the following amplification conditions for Ucp2: $95^{\circ} \mathrm{C}$ for $10 \mathrm{~min}$, Hot-start, then 35 cycles of denaturation at $95^{\circ} \mathrm{C}$ for $30 \mathrm{sec}$, annealing at $60^{\circ} \mathrm{C}$ for $30 \mathrm{sec}$ and amplification at $72^{\circ} \mathrm{C}$ for $30 \mathrm{sec}$. The same amount of cDNA was used in $25 \mu \mathrm{l}$ PCR reaction with AmpliTaq Gold Polymerase to detect Ucp1. PCR conditions for Ucp1 were: $95^{\circ} \mathrm{C}$ for $10 \mathrm{~min}$, Hot-start, followed by 3 cycles of denaturation at $95^{\circ} \mathrm{C}$ for $30 \mathrm{sec}$, annealing at $54^{\circ} \mathrm{C}$ for 10 sec, extension at $72^{\circ} \mathrm{C}$ for $30 \mathrm{sec}$; another 3 cycles at $95^{\circ} \mathrm{C}$ for $30 \mathrm{sec}, 56^{\circ} \mathrm{C}$ for $15 \mathrm{sec}$ and $72^{\circ} \mathrm{C}$ for $30 \mathrm{sec}$, and finally 35 cycles at $95^{\circ} \mathrm{C}$ for $30 \mathrm{sec}, 58^{\circ} \mathrm{C}$ for $30 \mathrm{sec}$ and $72^{\circ} \mathrm{C}$ for $30 \mathrm{sec}$. After the last cycle, samples were incubated for 5 min at $72^{\circ} \mathrm{C}$. $15 \mu \mathrm{l}$ of amplified products were then resolved on a $1 \%$ agarose gel, and DNA bands visualized under UV. Primers used to amplify mouse $U c p 1$ and $U c p 2$ products were UCP1-M F1， 5'-TATCATCACCTTCCCGCTG-3' (exon 1) ; UCP1-M R1, 5'-GTCATATGTTACCAGCTCTG-3' (exon 4), product size 505 bp; UCP2-M F2, 5'-TCTACAATGGGCTGGTCGC-3' (exon 4); UCP2-M R5, 5'-CAAGCGGAGAAAGGAAGGC-3' (exon 8), product size $608 \mathrm{bp}$. The quality of MIN-6 and $\alpha \mathrm{TC} 1.6 \mathrm{cDNA}$ was confirmed by PCR amplification of cyclophilin (data not shown).

\section{Immunohistochemistry}

Formalin-fixed, paraffin embedded Macaca fascicularis (monkey) pancreas was sectioned at $4 \mu \mathrm{m}$, and commercially obtained normal human (BioChain, Haywood, CA) and normal mouse pancreatic tissue sections (BioChain, Haywood, CA) were used. Triplicate slides for each species were used for the localization of (1) insulin, (2) UCP1, and (3) insulin and UCP1. After sections were deparaffinized, two sets of slides were incubated with Guinea pig anti-porcine insulin (DAKO, Carpinteria, CA) at 1:100 for 60 minutes at $34^{\circ} \mathrm{C}$, then incubated with biotinylated anti-rabbit at 1:20 (BioGenex, San Ramon, CA) for 10 minutes at $34^{\circ} \mathrm{C}$, and finally incubated for 20 minutes at $37^{\circ} \mathrm{C}$ with Streptavidin- $\beta$-Galactosidase at 1:250 (GibcoBRL, Gaithersburg, MD) and visualized using Gal-X. After performing antigen retrieval, insulin-stained as well as unstained sections were incubated with goat anti-UCP1 (Santa Cruz Biotechnology, Santa Cruz, CA) at 1:100 for 
one hour at room temperature, incubated 10 minutes at $34^{\circ} \mathrm{C}$ in biotinylated rabbit anti-goat (Jackson ImmunoResearch, West Grove, PA) at 1:250, then incubated with Streptavidin-Alkaline phosphatase (BioGenex, San Ramon, CA) at 1:20 for 10 minutes at $34^{\circ} \mathrm{C}$. Vector Red substrate (Vector Laboratories, Burlingame, CA) was used for visualization, and sections were counterstained with Mayer's hematoxylin. A MicroProbe system (Fisher Scientific, Kent, WA) using capillary action, and commercially purchased TRIS diluent and wash buffer (Biomeda, Foster City, CA) with $0.1 \%$ Tween 20 to serve as a surfactant and $0.5 \%$ casein to block non-specific binding of proteins were used.

\section{Results \\ Study sample}

Characteristics of the three IRAS Family Study populations are shown in Table 1 . The mean ages of the participating family members were $43.8 \pm 14.8$ years (Los Angeles), $40.3 \pm 14.0$ years (San Luis Valley) and $43.6 \pm$ 14.8 years (San Antonio), with $52.2-60.0 \%$ female participants. Using the Los Angeles population as the reference group, the mean age of the San Luis Valley participants is significantly lower than the Los Angeles participants ( $\mathrm{p}=$ 0.0057). The prevalence of diabetes in the San Antonio participants is higher than in the Los Angeles sample ( $\mathrm{p}=$ 0.046) and the mean $\mathrm{AIR}_{\mathrm{g}}$ in the San Antonio sample is significantly lower than that of the Los Angeles population $(\mathrm{p}=0.024)$. A higher $\mathrm{AIR}_{\mathrm{g}}$ in African American participants, when compared with Hispanic participants, has been reported previously for this study population
$[23,32,33]$. The mean waist measurement in San Antonio family members $(\mathrm{p}=0.043)$ is significantly greater than that of the Los Angeles participants; and the mean WHR in San Antonio ( $\mathrm{p}=0.0004)$ and San Luis Valley $(\mathrm{p}=$ 0.0028 ) samples are significantly higher than that of the Los Angeles sample. The mean HDL in San Antonio ( $\mathrm{p}<$ $0.0001)$ and San Luis Valley $(p=0.0057)$ families are both significantly lower than in the Los Angeles families.

\section{HWE, linkage disequilibrium between SNPs, and allele frequencies}

All SNPs were consistent with HWE, except for UCP1 A3826G in the San Antonio Hispanic population ( $\mathrm{P}=$ 0.034 for unrelated founder individuals, $n=73$ ). There was a single inconsistency (for UCP1 A64T in an individual from the San Luis Valley) among genotypes from 50 individuals included as blind duplicates, producing a genotyping error rate of $0.4 \%$ and a concordance rate of $>$ $99 \%$. UCP1 SNPs were in high LD, with $\mathrm{D}^{\prime}>0.90$ for all pairwise comparisons across all three populations using unrelated founders, except for A64T and M229L in the SA founders where $\mathrm{D}^{\prime}=0.80$. LD between the two UCP2 SNPs was high, with D' $>0.97$ across all three populations. Genotype frequencies are shown in Table 2. UCP1 SNPs A64T and M229L were relatively rare, and recessive effects of these SNPs were disregarded in this study.

\section{Association between UCPI and AIR}

A significant association was observed between UCP1 A3826G and $\mathrm{AIR}_{\mathrm{g}}$ in African American families (GEE empirical $\mathrm{P}=0.006$, dominant model; Table 3). There was bor-

Table 2: Genotype frequencies for UCPI and UCP2 SNPs in populations from the IRAS Family Study

\begin{tabular}{|c|c|c|c|c|c|}
\hline & & & \multirow{2}{*}{$\begin{array}{l}\text { African American } \\
\text { Los Angeles }\end{array}$} & \multicolumn{2}{|c|}{ Hispanic } \\
\hline & & & & San Luis Valley & San Antonio \\
\hline \multirow[t]{12}{*}{ UCPI } & A-3826G & $\mathrm{A} / \mathrm{A}, \%(\mathrm{n})^{*}$ & $17.4(50)$ & $34.0(108)$ & $35.2(174)$ \\
\hline & & $\mathrm{A} / \mathrm{G}, \%(\mathrm{n})$ & $40.4(116)$ & $51.9(165)$ & $50.4(249)$ \\
\hline & & $\mathrm{G} / \mathrm{G}, \%(\mathrm{n})$ & $42.2(121)$ & $14.2(45)$ & $14.4(7 \mid)$ \\
\hline & & Total (n) & $(287)$ & $(318)$ & $(494)$ \\
\hline & A64T & $\mathrm{G} / \mathrm{G}, \%(\mathrm{n})$ & $83.1(236)$ & $83.8(263)$ & 83.1 (409) \\
\hline & & $\mathrm{G} / \mathrm{A}, \%(\mathrm{n})$ & $16.2(46)$ & $15.6(49)$ & $15.9(78)$ \\
\hline & & $A / A, \%(n)$ & $0.7(2)$ & $0.6(2)$ & $1.0(5)$ \\
\hline & & Total $(n)$ & $(284)$ & $(314)$ & $(492)$ \\
\hline & M229L & $\mathrm{A} / \mathrm{A}, \%(\mathrm{n})$ & $93.0(264)$ & $84.4(265)$ & $82.9(402)$ \\
\hline & & $\mathrm{A} / \mathrm{T}, \%(\mathrm{n})$ & $7.0(20)$ & $14.7(46)$ & $16.1(78)$ \\
\hline & & $\mathrm{T} / \mathrm{T}, \%(\mathrm{n})$ & $0(0)$ & $1.0(3)$ & $1.0(5)$ \\
\hline & & Total (n) & $(284)$ & $(3 \mid 4)$ & $(485)$ \\
\hline \multirow[t]{8}{*}{ UCP2 } & G-866A & $\mathrm{G} / \mathrm{G}, \%(\mathrm{n})$ & $32.8(89)$ & $31.1(94)$ & $27.2(132)$ \\
\hline & & $\mathrm{G} / \mathrm{A}, \%(\mathrm{n})$ & $48.0(130)$ & 48.7 (I47) & $46.7(227)$ \\
\hline & & $A / A, \%(n)$ & $19.2(52)$ & $20.2(6 \mathrm{I})$ & $26.1(127)$ \\
\hline & & Total $(n)$ & $(27 I)$ & $(302)$ & $(486)$ \\
\hline & A55V & C/C, \% (n) & $28.8(82)$ & $28.3(89)$ & $26.3(129)$ \\
\hline & & $C / T, \%(n)$ & $51.2(146)$ & $53.3(168)$ & $47.4(232)$ \\
\hline & & $\mathrm{T} / \mathrm{T}, \%(\mathrm{n})$ & $20.0(57)$ & $18.4(58)$ & $26.3(129)$ \\
\hline & & Total (n) & $(285)$ & $(3 \mid 5)$ & $(490)$ \\
\hline
\end{tabular}

$*_{n}=$ the number of individuals successfully genotyped. 
Table 3: Significant association results between UCPI and UCP2 SNPs and traits in populations from the IRAS Family Study

\begin{tabular}{|c|c|c|c|c|c|c|c|c|c|c|c|}
\hline Trait & Population & Gene & SNP & $\begin{array}{l}\text { Allele I/ } \\
\text { Allele } 2\end{array}$ & $\underset{(\text { (n) }}{\operatorname{Mean} \pm \text { SE I/I }}$ & $\underset{(\mathrm{n})}{\operatorname{Mean} \pm \text { SE I/2 }}$ & $\underset{(n)}{\operatorname{Mean} \pm \text { SE 2/2 }}$ & $\begin{array}{l}\text { P-value } \\
\text { (General) }\end{array}$ & $\begin{array}{l}\text { P-value } \\
\text { (Dom) }\end{array}$ & $\begin{array}{l}\text { P-Value } \\
\text { (Add) }\end{array}$ & $\begin{array}{c}\text { P-value } \\
\text { (Rec) }\end{array}$ \\
\hline $\mathrm{AIR}_{\mathrm{g}}^{\mathrm{a}}$ & Los Angeles & UCPI & A3826G & $\mathrm{A} / \mathrm{G}$ & $669.4 \pm 86.3(42)$ & $954.2 \pm 83.9(93)$ & $894.7 \pm 65.1(98)$ & 0.017 & 0.006 & 0.366 & 0.786 \\
\hline $\operatorname{AIR}_{\mathrm{g}}^{\mathrm{g}}$ & $\begin{array}{l}\text { San Luis } \\
\text { Valley }\end{array}$ & $U C P I$ & A3826G & $\mathrm{A} / \mathrm{G}$ & $718.4 \pm 110.5(74)$ & $867.3 \pm 81.9(117)$ & $855.9 \pm 80.2(23)$ & 0.161 & 0.054 & 0.093 & 0.366 \\
\hline BMIb & San Antonio & UCP2 & A55V & $\mathrm{C} / \mathrm{T}$ & $29.2 \pm 0.82(115)$ & $28.7 \pm 0.54(210)$ & $30.3 \pm 0.71(116)$ & 0.040 & 0.968 & 0.220 & 0.018 \\
\hline Waist ${ }^{b}$ & Los Angeles & UCP2 & A55V & $\mathrm{C} / \mathrm{T}$ & $88.1 \pm 0.60(76)$ & $87.1 \pm 0.49(139)$ & $89.4 \pm 0.67(54)$ & 0.045 & 0.440 & 0.510 & 0.065 \\
\hline$W H^{b}$ & Los Angeles & UCP2 & G-866A & G/A & $0.82 \pm 0.005(77)$ & $0.81 \pm 0.005(130)$ & $0.83 \pm 0.007(5 \mathrm{I})$ & 0.016 & 0.237 & 0.863 & 0.037 \\
\hline $\mathrm{HDL}^{\mathrm{a}}$ & San Antonio & UCPI & A3826G & $\mathrm{A} / \mathrm{G}$ & $40.2 \pm 1.14(164)$ & $42.8 \pm 1.10(217)$ & $44.9 \pm 1.46(66)$ & 0.001 & 0.015 & 0.0004 & 0.006 \\
\hline
\end{tabular}

Empirical P-values are shown. aAdjusted for age, sex and BMI; badjusted for age and sex. General: General model; Dom: Dominant model; Add: Additive model; Rec: Recessive model. Bold: $P<0.05$.

derline evidence for an association between A-3826G and $\mathrm{AIR}_{\mathrm{g}}$ in Hispanic families from San Luis Valley, Colorado (GEE empirical $\mathrm{P}=0.054$, dominant model). Although the initial GEE analysis provided evidence of an association between $\mathrm{A} 64 \mathrm{~T}$ and $\mathrm{AIR}_{\mathrm{g}}$ in African Americans (unadjusted $\mathrm{p}<0.001$, general model; $\mathrm{P}=0.038$, additive model), this result was driven by the presence of two minor allele homozygotes with high AIR $_{\mathrm{g}}$ values and was not supported by simulation-based empirical $\mathrm{p}$-values ( $\mathrm{P}$ $=0.116$, general model; $\mathrm{P}=0.110$, additive model). Haplotypic association analyses of these two SNPs using QPDT [31] were not significant (data not shown).

\section{Other significant associations}

Four other significant associations were detected (Table 3 ), with the majority related to measures of adiposity. $U C P 2 \mathrm{~A} 55 \mathrm{~V}$ was associated with waist circumference $(\mathrm{P}=$ $0.045)$ and $U C P 2 \mathrm{G}-866 \mathrm{~A}$ with WHR in AA $(\mathrm{P}=0.016)$, although only in analyses unadjusted for BMI (but adjusted for age and sex). UCP2 $\mathrm{A} 55 \mathrm{~V}$ was also associated with $\mathrm{BMI}$ in SA $(\mathrm{P}=0.018)$, and UCP1 A-3826G was associated with HDL-C levels in SA families $(P=0.0004)$ after adjustment for age and sex. Even though associations with UCP2 A55V were across different populations, the direction of effects was consistent, with the $55 \mathrm{~V} / 55 \mathrm{~V}$ genotype associated with both greater waist circumference and higher BMI.

\section{RT-PCR of UCPI and UCP2}

Results of the RT-PCR analyses using total human pancreatic RNA are shown in Figure 1. There was no product visible when the protocol was carried out without the addition of RT enzyme (-RT control; Figure 1, lanes 3 and 4 ), indicating no detectable contamination with genomic DNA. A band representing the UCP1 product ( $489 \mathrm{~kb}$ ) can be seen in Figure 1, lane 6 . The identity of this band as the expected UCP1 product was confirmed by sequencing. A second spurious band is also seen in lane 6 at $381 \mathrm{bp}$. This product was also sequenced and BLAST searches [34] indicated $98 \%$ homology to a region of the SAR1 gene on $10 \mathrm{q} 22.1$. There is only $13 \%$ homology between this product and the UCP1 product, however there is an 8-base region in the $U C P 1$ forward primer and a 6-base sequence in the UCP1 reverse primer that are identical to regions in the SAR1 gene. These sequences immediately flank the SAR1-like sequence obtained and may have served as an anchor to allow amplification. We never detected UCP1 expression in the absence of the SAR1 band. As expected, a $495 \mathrm{~kb}$ band derived from UCP2 is present in Figure 1, lane 7 and its origin was also confirmed by sequencing. Expression of UCP1 was also detected at low levels in the murine beta cell line MIN-6 (Figure 2, lane 2), but was absent in the murine glucagon-secreting cell line $\alpha \mathrm{TC} 1.6$ (Figure 2, lane 6).

\section{Immunohistochemistry of pancreatic sections}

Results of the IHC experiments are shown in Figure 3. UCP1 protein was detected in pancreatic tissue sections from Macaca fascicularis (monkey), human, and mouse, and co-localized with insulin in the islet cells of all three species. As anticipated from its known mitochondrial localization, UCP1 protein was only observed in the cytosol.

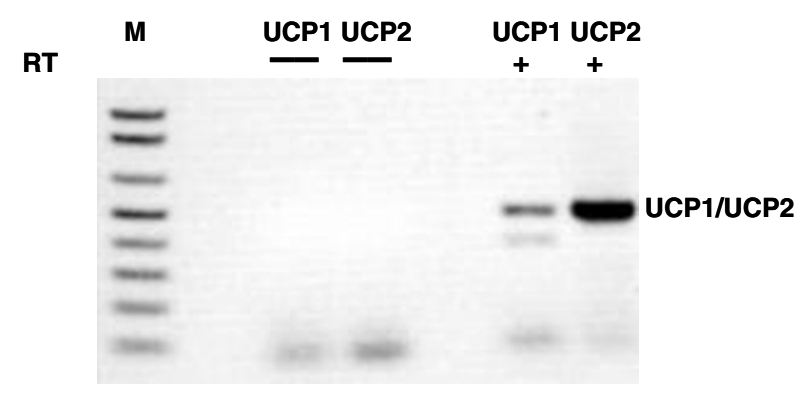

\section{Figure I}

UCPI is expressed in human total pancreatic RNA: cDNAs prepared in the absence or presence of reverse transcriptase (RT) from total human pancreas RNA, were used for PCR with the indicated primers. The lane containing I Kb Plus DNA Ladder (M), and positions of UCPI (489 bp) and UCP2 products (495 bp) in the lanes corresponding to RT+ cDNA are indicated. 


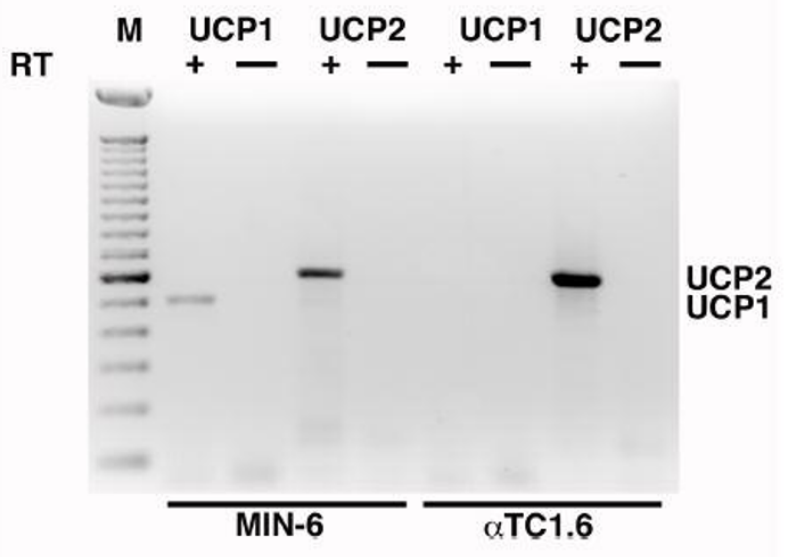

Figure 2

Ucpl is expressed in an insulin producing cell line: cDNAs prepared in the absence or presence of reverse transcriptase (RT) from total RNA isolated from MIN-6 and $\alpha \mathrm{TCI} .6$ cells, were used for PCR with the indicated primers. The lane containing 100 bp marker (M), and positions of Ucp I and Ucp2 products are indicated. A band corresponding to Ucp I (505 bp) can be clearly seen in the lane corresponding to RT+ MIN-6 cDNA. Expression of Ucp2 (608 bp) can be seen in both insulin and glucagon producing cell lines.

\section{Discussion}

As anticipated, associations were detected between genotyped SNPs and metabolic traits, particularly with measures related to adiposity: UCP2 SNPs with waist circumference, BMI and waist-to-hip ratio, although significance levels for these associations were modest (Table 3). An association between UCP1 A-3826G and HDL-C levels in SA families ( $\mathrm{P}=0.0004)$ was also detected. The association between UCP1 A-3826G and $\mathrm{AIR}_{\mathrm{g}}$ in the AA families from the IRAS Family Study was unexpected, since UCP1 has not been reported to be expressed in the pancreas.

In both the original IRAS cohort [35], and the IRAS Family Study [32], AIR was found to be higher in non-diabetic African Americans than non-Hispanic whites or Hispanics. Carrying either the UCP1 3826G allele or the rare 64T allele increases $\mathrm{AIR}_{\mathrm{g}}$ (although the latter association was not statistically significant). The higher frequency of $3826 \mathrm{G}$ in the African American families investigated appears to at least partially explain the higher $\mathrm{AIR}_{\mathrm{g}}$ values. We did not find significant association with $\mathrm{AIR}_{\mathrm{g}}$ using haplotype analysis of the two UCP1 SNPs, and there is insufficient power in the present study design to investigate whether the presence of the two SNPs in trans show an interaction. Interestingly, threonine is present at position 64 in dog, mouse, rat, hamster, rabbit, Arabidopsis and Solanum Ucp1, and also present in human UCP2 and
UCP3, although alanine is the more common amino acid in UCP1 of humans. It is not known what effect substituting a hydrophilic amino acid (threonine) for a hydrophobic residue (alanine) at this position has on protein function, especially in relation to insulin secretion.

While UCP2 is expressed in a variety of tissues [36], UCP1 expression was believed to be largely restricted to brown adipose tissue (BAT) [36-38]. However, expression of $u c p 1$ in mouse brain, skeletal muscle [39] and uterus [40], and rat thymus [41] have been reported. The rapid insulin response measured by $\mathrm{AIR}_{\mathrm{g}}$ is generally believed to be a measure of beta cell function, and we therefore sought to explain the biological impact of UCP1 on $\mathrm{AIR}_{\mathrm{g}}$ by investigating the expression of this gene in the pancreas. Detection of UCP1 expression in human pancreas by RT-PCR is a novel finding. We confirmed the presence of UCP1 in human pancreas by IHC and found the UCP1 protein COlocalized with insulin in the islets. Further, RT-PCR of the murine beta cell line MIN-6 demonstrated the presence of UCP1 expression in beta cells, while UCP1 mRNA could not be detected in the murine alpha cell derived line aTC1.6.

UCP2 is known to be expressed in pancreatic islets, where it is upregulated by glucolipotoxic conditions, and increased UCP2 expression decreases glucose-stimulated insulin secretion $[42,43]$. Even though UCP2 G866A has been reported by others as influencing glucose-induced insulin secretion [3-5], we did not see any association between this SNP and $\mathrm{AIR}_{\mathrm{g}}$. Over-expression studies of $u c p 1$ in INS-1 cells have shown that ucp1 upregulation also suppresses insulin secretion [44], while studies of adipose tissues indicated that the promoter $-3826 \mathrm{G}$ allele decreases UCP1 expression [45]. Assuming the same impact on expression is true in human beta cells, this would be consistent with the increased first-phase insulin response (or lack of suppression) seen individuals from Los Angeles and San Luis Valley with one or two copies of the UCP1 -3826G allele.

The polygenic regulation of $\mathrm{AIR}_{\mathrm{g}^{\prime}}$ and implication from expression studies that other sequence variants are likely to influence UCP1 expression [45], may explain the more modest effects (San Luis Valley) or lack of association (San Antonio) seen between UCP1 A-3826G and AIR ${ }_{\mathrm{g}}$ in the two Hispanic populations.

Associations between UCP2 SNPs and waist or WHR were modest and have not been reported previously, although UCP2 G-866A and A55V have been reported as associated with BMI [46-48], and G-866A associated with obesity [8] and adipose tissue levels [4]. The -866A allele is associated with enhanced UCP2 mRNA expression in adipose tissue [8], possibly via PAX6 transactivation [49]. However, 

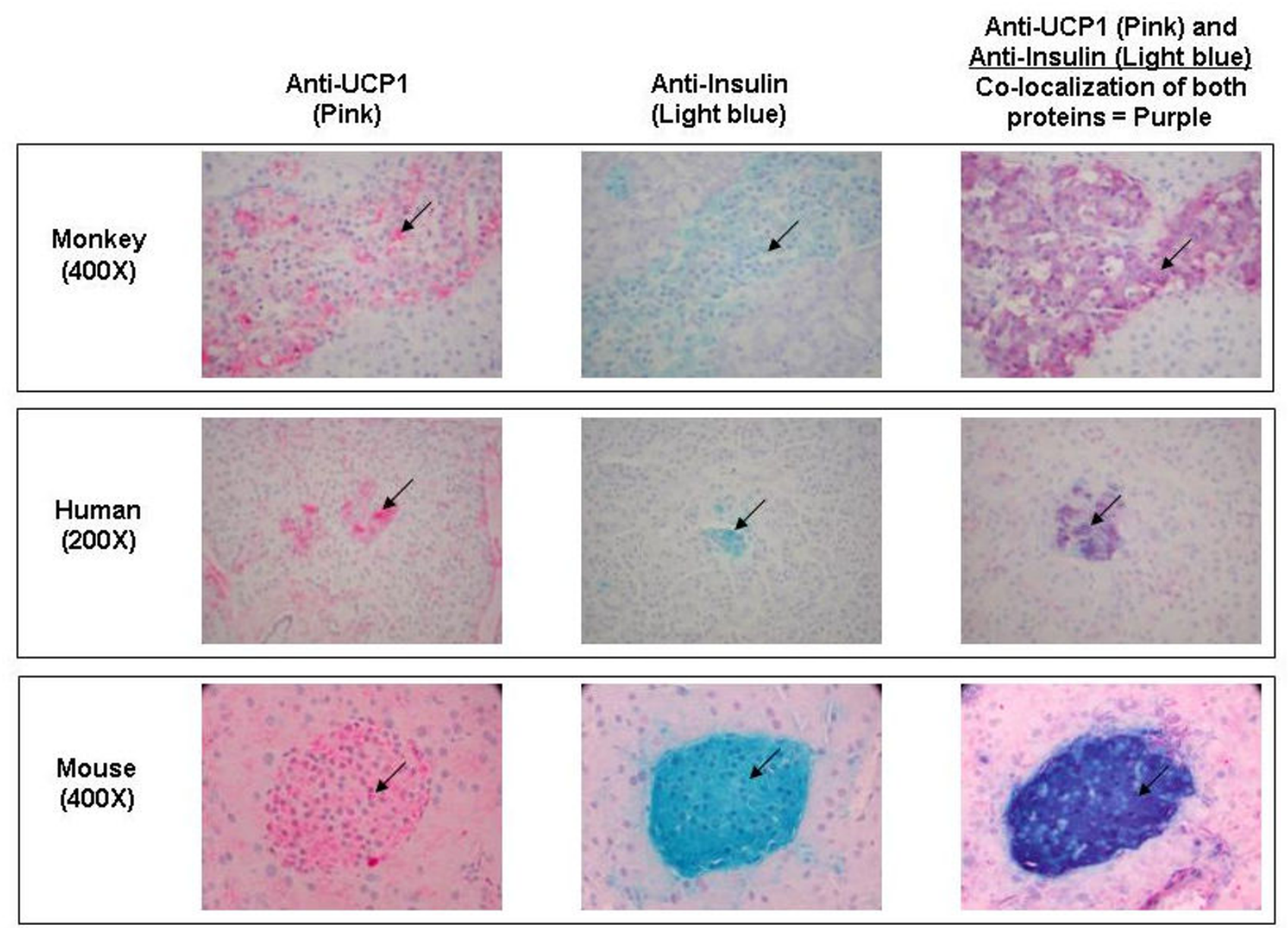

\section{Figure 3}

UCPI and insulin co-localize in mammalian islet cells. Pancreas sections from monkey (Macaca fascicularis), human, and mouse (indicated at left, together with magnification) were stained using immunohistochemistry with anti-UCPI (left); anti-Insulin (middle); or double-stained with anti-UCPI and anti-Insulin (right). Sections stained with anti-UCPI were visualized with Vector Red, resulting in pink staining of the islet cells, seen in the left panel for each species. Gal-X visualization of anti-Insulin produced a light blue stain of islet cell cytoplasm, seen in the middle panel for each species. Co-localization (overlay) of both antiUCPI (pink) and anti-Insulin (light blue) stains produced the purple staining of the islets seen in the third panel for each species. Examples of islet cells with cytoplasmic staining for the proteins of interest are indicated by the arrows.

commonly reported associations between obesity and the UCP1 SNPs genotyped were not detected. The reported association between UCP1 A-3826G and obesity in Spanish women [50] was not observed in Hispanic families, possibly due to different environmental interactions. The smallest P-value for this SNP with the 2 degree-of freedom general test of association and measures of obesity was $\mathrm{P}$ $=0.14$ for BMI in San Luis Valley women.

Interestingly, the same UCP1 SNP associated with high $\mathrm{AIR}_{\mathrm{g}}$ in AA, 3826G, was also significantly associated with higher HDL-C levels in the Hispanic SA families, although it should be noted that this SNP deviated from HW proportions $(\mathrm{P}=0.034)$ in the 73 founders in this popula- tion. In a study of 312 Japanese women, there was a nonsignificant trend for women carrying the $3826 \mathrm{G}$ allele to have higher HDL levels than non-carriers, in both premenopausal $(P=0.14)$ and postmenopausal $(P=0.29)$ groups [51]. However a study of 118 obese Polish subjects showed $3826 \mathrm{G} / \mathrm{G}$ homozygotes $(\mathrm{n}=17)$ had significantly lower levels of HDL-C than AA homozygotes $(n=63)(P=$ $0.004)$ [52], opposite to the results observed in the SA families of the IRAS Family Study.

Tests of association for additional traits (such as hypertension and coagulation factors) that were not part of our $a$ priori hypotheses for either UCP1 or UCP2 were conducted during automated analytical procedures. After 
Bonferroni correction for 5 SNPs $\times 21$ traits $\times 4$ models + 4 haplotypic analyses, none of the reported associations would maintain significance. However, all tests can not be considered entirely independent due to correlations between SNPs and across phenotypes, so this approach may be overly conservative. Additionally, we did not consider the inheritance models unless the general test of association was significant. While a trend between UCP1 3826G and higher HDL-C levels detected in the SA population has been reported previously [51], clearly replication of the association between this SNP and $\mathrm{AIR}_{\mathrm{g}}$ in other populations will be needed to confirm this finding.

\section{Conclusion}

We have confirmed the previously-reported association between UCP1 A-3826G and HDL-C levels in a Hispanic population from the IRAS Family Study. We also found a novel association between UCP1 A-3826G and $\mathrm{AIR}_{\mathrm{g}}$ in an African American population, and detected UCP1 expression in primate and mouse islet cells. These results suggest that UCP1 may have a previously unsuspected role in firstphase insulin release. Further studies of the influence of variants of the $U C P 1$ gene on $\mathrm{AIR}_{\mathrm{g}}$ in other populations, and investigations of the interplay between UCP1 and UCP2 on glucose-stimulated insulin secretion, are warranted.

\section{Abbreviations}

UCP: uncoupling protein; $\mathrm{AIR}_{\mathrm{g}}$ : acute insulin response to glucose; QPDT: quantitative pedigree disequilibrium test; HWE: Hardy Weinberg equilibrium

\section{Competing interests}

The author(s) declare that they have no competing interests.

\section{Authors' contributions}

MMS reviewed association results, planned expression and immunohistochemistry experiments, and drafted the manuscript. FCH conducted statistical analyses. NDP selected SNPs and performed genotyping assays. CJG and KLK conducted RT-PCR and sequencing assays of human pancreas, while RT-PCR of MIN-6 and $\alpha \mathrm{TC} 1.6$ cells were provided by AJS. HMB conducted the immunohistochemistry experiments. RNB, MFS, and JMN were involved in the conception, design and phenotypic characterization of the IRAS Family Study. MFS and JMN also played a key role in recruitment, and KDT contributed to genotypic characterization of the population. All authors read and approved the final manuscript.

\section{Acknowledgements}

We wish to thank participants in the IRAS Family Study for their participation. Thanks also to Pam Hicks, Elyse Jung, and Federico Paroni for technical assistance, Dr Carl Langefeld, Dr Stephen Rich, Stephanie Beck and Joel Campbell for statistical assistance, Dr Donald Bowden for initiating geno- typing and comments on the manuscript, and Drs J. Mark Cline and Nancy Kock for advice on immunohistochemistry experiments. This work was supported by the National Institutes of Health grants HL060944, HL060894, HL06I 210 , HL06093 I, HL06I019, HL06I 210 and DK66358. MMS is supported by a Career Development Award from the American Diabetes Association.

\section{References}

I. Ledesma A, de Lacoba MG, Rial E: The mitochondrial uncoupling proteins. Genome Biol 2002, 3:REVIEWS30I5.

2. Chan $C B$ : Endogenous regulation of insulin secretion by UCP2. Clin Lab 2002, 48:599-604.

3. Sesti G, Cardellini M, Marini MA, Frontoni S, D'Adamo M, Del Guerra S, Lauro D, De Nicolais P, Sbraccia P, Del Prato S, Gambardella S, Federici M, Marchetti $P$, Lauro $R$ : A common polymorphism in the promoter of UCP2 contributes to the variation in insulin secretion in glucose-tolerant subjects. Diabetes 2003, 52: $1280-1283$.

4. Wang H, Chu WS, Lu T, Hasstedt SJ, Kern PA, Elbein SC: Uncoupling protein-2 polymorphisms in type 2 diabetes, obesity, and insulin secretion. Am J Physiol Endocrinol Metab 2004, 286:EI-7.

5. Sasahara M, Nishi M, Kawashima H, Ueda K, Sakagashira S, Furuta $H$, Matsumoto E, Hanabusa T, Sasaki H, Nanjo K: Uncoupling protein 2 promoter polymorphism $-866 \mathrm{G} / \mathrm{A}$ affects its expression in beta-cells and modulates clinical profiles of Japanese type $\mathbf{2}$ diabetic patients. Diabetes 2004, 53:482-485.

6. Walder K, Norman RA, Hanson RL, Schrauwen P, Neverova M, Jenkinson CP, Easlick J, Warden CH, Pecqueur C, Raimbault S, Ricquier D, Silver MH, Shuldiner AR, Solanes G, Lowell BB, Chung WK, Leibel RL, Pratley R, Ravussin E: Association between uncoupling protein polymorphisms (UCP2-UCP3) and energy metabolism/obesity in Pima indians. Hum Mol Genet 1998, 7:1431-I435.

7. Astrup A, Toubro S, Dalgaard LT, Urhammer SA, Sorensen TI, Pedersen O: Impact of the v/v $\mathbf{5 5}$ polymorphism of the uncoupling protein 2 gene on 24-h energy expenditure and substrate oxidation. Int J Obes Relat Metab Disord 1999, 23: 1030-1034.

8. Esterbauer H, Schneitler C, Oberkofler H, Ebenbichler C, Paulweber B, Sandhofer F, Ladurner G, Hell E, Strosberg AD, Patsch JR, Krempler $F$, Patsch W: A common polymorphism in the promoter of UCP2 is associated with decreased risk of obesity in middle-aged humans. Nat Genet 200I, 28: 178-I83.

9. Dalgaard LT, Pedersen O: Uncoupling proteins: functional characteristics and role in the pathogenesis of obesity and Type II diabetes. Diabetologia 200I, 44:946-965.

10. Hamann A, Tafel J, Busing B, Munzberg H, Hinney A, Mayer H, Siegfried W, Ricquier D, Greten H, Hebebrand J, Matthaei S: Analysis of the uncoupling protein-I (UCPI) gene in obese and lean subjects: identification of four amino acid variants. Int J Obes Relat Metab Disord 1998, 22:939-94I.

1I. Heilbronn LK, Kind KL, Pancewicz E, Morris AM, Noakes M, Clifton PM: Association of $-3826 \mathrm{G}$ variant in uncoupling protein-I with increased BMI in overweight Australian women. Diabetologia 2000, 43:242-244.

12. Salopuro T, Lindstrom J, Eriksson JG, Valle TT, Hamalainen H, llanneParikka P, Keinanen-Kiukaanniemi S, Tuomilehto J, Laakso M, Uusitupa M: Common variants in beta2- and beta3-adrenergic receptor genes and uncoupling protein $I$ as predictors of the risk for type 2 diabetes and body weight changes. The Finnish Diabetes Prevention Study. Clin Genet 2004, 66:365-367.

13. Mori H, Okazawa H, Iwamoto K, Maeda E, Hashiramoto M, Kasuga $M: A$ polymorphism in the 5 ' untranslated region and a Met229-->Leu variant in exon 5 of the human UCPI gene are associated with susceptibility to type II diabetes mellitus. Diabetologia 200I, 44:373-376.

14. Henkin L, Bergman RN, Bowden DW, Ellsworth DL, Haffner SM, Langefeld CD, Mitchell BD, Norris JM, Rewers M, Saad MF, Stamm E, Wagenknecht LE, Rich SS: Genetic epidemiology of insulin resistance and visceral adiposity. The IRAS Family Study design and methods. Ann Epidemiol 2003, 13:211-217.

15. Wagenknecht LE, Mayer EJ, Rewers M, Haffner S, Selby J, Borok GM, Henkin L, Howard G, Savage PJ, Saad MF: The insulin resistance atherosclerosis study (IRAS) objectives, design, and recruitment results. Ann Epidemiol 1995, 5:464-472. 
16. Herbert V, Lau KS, Gottlieb CW, Bleicher SJ: Coated charcoal immunoassay of insulin. J Clin Endocrinol Metab 1965, 25:1375-1384.

17. Steil GM, Volund A, Kahn SE, Bergman RN: Reduced sample number for calculation of insulin sensitivity and glucose effectiveness from the minimal model. Suitability for use in population studies. Diabetes 1993, 42:250-256.

18. Pacini G, Bergman RN: MINMOD: a computer program to calculate insulin sensitivity and pancreatic responsivity from the frequently sampled intravenous glucose tolerance test. Comput Methods Programs Biomed 1986, 23: I I3-I 22.

19. Friedewald WT, Levy RI, Fredrickson DS: Estimation of the concentration of low-density lipoprotein cholesterol in plasma, without use of the preparative ultracentrifuge. Clin Chem 1972, I 8:499-502.

20. Sugiuchi H, Uji Y, Okabe H, Irie T, Uekama K, Kayahara N, Miyauchi $\mathrm{K}$ : Direct measurement of high-density lipoprotein cholesterol in serum with polyethylene glycol-modified enzymes and sulfated alpha-cyclodextrin. Clin Chem 1995, 41:71 7-723.

21. Buetow KH, Edmonson M, MacDonald R, Clifford R, Yip P, Kelley J, Little DP, Strausberg R, Koester H, Cantor CR, Braun A: Highthroughput development and characterization of a genomewide collection of gene-based single nucleotide polymorphism markers by chip-based matrix-assisted laser desorption/ionization time-of-flight mass spectrometry. Proc Natl Acad Sci U S A 200I, 98:58I-584.

22. McPeek MS, Sun L: Statistical tests for detection of misspecified relationships by use of genome-screen data. Am J Hum Genet 2000, 66:1076-1094.

23. Rich SS, Bowden DW, Haffner SM, Norris JM, Saad MF, Mitchell BD, Rotter JI, Langefeld CD, Wagenknecht LE, Bergman RN: Identification of quantitative trait loci for glucose homeostasis: the Insulin Resistance Atherosclerosis Study (IRAS) Family Study. Diabetes 2004, 53:1866-1875.

24. O'Connell JR, Weeks DE: PedCheck: a program for identification of genotype incompatibilities in linkage analysis. $\mathrm{Am} J$ Hum Genet 1998, 63:259-266.

25. Devlin B, Risch N: A comparison of linkage disequilibrium measures for fine-scale mapping. Genomics 1995, 29:3 | I-322

26. Lange K: Mathematical and statistical methods for genetic analysis. New York, Springer; 1997.

27. Zeger SL, Liang KY: Longitudinal data analysis for discrete and continuous outcomes. Biometrics 1986, 42:121-130.

28. Diggle PJ, Heagerty PJ, Liang KY, Zeger SL: Analysis of longitudinal data. 2nd edition. New York: Oxford University Press; 2002.

29. Neter JWW, Kutner MH: Applied linear statistical models, regression, analysis of variance, and experimental design. Homewood, IL, Richard D. Irwin, Inc.; 1990.

30. Lange K, Cantor R, Horvath S, Perola M, Sabatti C, Sinsheimer J, Sobel $E$ : Mendel version 4.0: A complete package for exact genetic analysis of discrete traits in pedigrees and population data sets. Am J Hum Genet 200I, 69 Supplement.:Al 886.

31. Dudbridge F: Pedigree disequilibrium tests for multilocus haplotypes. Genet Epidemiol 2003, 25: I I5-I2I.

32. Wagenknecht LE, Langefeld CD, Scherzinger AL, Norris JM, Haffner SM, Saad MF, Bergman RN: Insulin sensitivity, insulin secretion, and abdominal fat: the Insulin Resistance Atherosclerosis Study (IRAS) Family Study. Diabetes 2003, 52:2490-2496.

33. Mitchell BD, Zaccaro D, Wagenknecht LE, Scherzinger AL, Bergman RN, Haffner SM, Hokanson J, Norris JM, Rotter JI, Saad MF: Insulin sensitivity, body fat distribution, and family diabetes history: the IRAS Family Study. Obes Res 2004, I 2:83 I-839.

34. Altschul SF, Gish W, Miller W, Myers EW, Lipman DJ: Basic local alignment search tool. I Mol Biol I990, 2 I 5:403-4IO.

35. Haffner SM, Howard G, Mayer E, Bergman RN, Savage PJ, Rewers M, Mykkanen L, Karter AJ, Hamman R, Saad MF: Insulin sensitivity and acute insulin response in African-Americans, non-Hispanic whites, and Hispanics with NIDDM: the Insulin Resistance Atherosclerosis Study. Diabetes 1997, 46:63-69.

36. Ricquier $\mathrm{D}$, Bouillaud $\mathrm{F}$ : The uncoupling protein homologues: UCP I, UCP2, UCP3, StUCP and AtUCP. Biochem J 2000, 345 Pt 2:161-179.

37. Nicholls DG, Locke RM: Thermogenic mechanisms in brown fat. Physiol Rev 1984, 64: I-64.

38. Nicholls DG: A history of UCPI. Biochem Soc Trans 200I, 29:75I-755
39. Lengacher S, Magistretti PJ, Pellerin L: Quantitative rt-PCR analysis of uncoupling protein isoforms in mouse brain cortex: methodological optimization and comparison of expression with brown adipose tissue and skeletal muscle. I Cereb Blood Flow Metab 2004, 24:780-788.

40. Nibbelink M, Moulin K, Arnaud E, Duval C, Penicaud L, Casteilla L: Brown fat UCPI is specifically expressed in uterine longitudinal smooth muscle cells. J Biol Chem 200I, 276:47291-47295.

4I. Carroll AM, Haines LR, Pearson TW, Brennan C, Breen EP, Porter RK: Immunodetection of UCPI in rat thymocytes. Biochem Soc Trans 2004, 32: 1066-1067.

42. Zhang CY, Baffy G, Perret $P$, Krauss S, Peroni O, Grujic D, Hagen T, Vidal-Puig AJ, Boss O, Kim YB, Zheng XX, Wheeler MB, Shulman GI, Chan $C B$, Lowell BB: Uncoupling protein-2 negatively regulates insulin secretion and is a major link between obesity, beta cell dysfunction, and type 2 diabetes. Cell 200I, 105:745-755.

43. Chan CB, De Leo D, Joseph JW, McQuaid TS, Ha XF, Xu F, Tsushima RG, Pennefather PS, Salapatek AM, Wheeler MB: Increased uncoupling protein-2 levels in beta-cells are associated with impaired glucose-stimulated insulin secretion: mechanism of action. Diabetes 200I, 50:1302-1310.

44. Nakazaki M, Kakei M, Ishihara $H$, Koriyama N, Hashiguchi $H$, Aso K, Fukudome M, Oka Y, Yada T, Tei C: Association of upregulated activity of K(ATP) channels with impaired insulin secretion in UCPI-expressing insulinoma cells. J Physiol 2002, 540:78I-789.

45. Esterbauer H, Oberkofler H, Liu YM, Breban D, Hell E, Krempler F, Patsch W: Uncoupling protein-I mRNA expression in obese human subjects: the role of sequence variations at the uncoupling protein-I gene locus. J Lipid Res 1998, 39:834-844.

46. Pinkney JH, Boss O, Bray GA, Bulmer K, Coppack SW, Mohamed-Ali $\mathrm{V}$ : Physiological relationships of uncoupling protein-2 gene expression in human adipose tissue in vivo. J Clin Endocrinol Metab 2000, 85:23।2-23I7.

47. Schonfeld-Warden NA, Warden CH: Physiological effects of variants in human uncoupling proteins: UCP2 influences bodymass index. Biochem Soc Trans 200I, 29:777-784.

48. Zheng Y, Xiang K, Zhang R, jia W, Lu J, Tang ], Li J: [The association between A55V variant in UCP2 gene and body fat distribution, serum lipid profile in Chinese]. Zhonghua $Y_{i} X u e Y_{i}$ Chuan Xue Za Zhi 2000, 17:97-100.

49. Krempler F, Esterbauer $\mathrm{H}$, Weitgasser R, Ebenbichler C, Patsch JR, Miller K, Xie M, Linnemayr V, Oberkofler H, Patsch W: A functional polymorphism in the promoter of UCP2 enhances obesity risk but reduces type 2 diabetes risk in obese middle-aged humans. Diabetes 2002, 5 I:333I-3335.

50. Ramis JM, Gonzalez-Sanchez JL, Proenza AM, Martinez-Larrad MT, Fernandez-Perez C, Palou A, Serrano-Rios M: The Arg64 allele of the beta 3-adrenoceptor gene but not the $-3826 \mathrm{G}$ allele of the uncoupling protein I gene is associated with increased leptin levels in the Spanish population. Metabolism 2004, 53(II): $1411-14 \mid 6$.

5I. Matsushita H, Kurabayashi T, Tomita M, Kato N, Tanaka K: Effects of uncoupling protein $I$ and beta3-adrenergic receptor gene polymorphisms on body size and serum lipid concentrations in Japanese women. Maturitas 2003, 45:39-45.

52. Kiec-Wilk B, Wybranska I, Malczewska-Malec M, Leszczynska-Golabek L, Partyka L, Niedbal S, Jabrocka A, Dembinska-Kiec A: Correlation of the -3826A $>G$ polymorphism in the promoter of the uncoupling protein I gene with obesity and metabolic disorders in obese families from southern Poland. J Physiol Pharmacol 2002, 53:477-490.

\section{Pre-publication history}

The pre-publication history for this paper can be accessed here:

http://www.biomedcentral.com/1472-6823/7/1/prepub 